\title{
DIÁLOGOS ENTRE SABERES INDÍGENAS E INDIGENISTAS: CONVERSA COM LYNN MARIO Trindade Menezes de Souza E Daniel Iberê GUARANI M'BYÁ
}

\author{
Lynn Mario Trindade Menezes de Souza* \\ Daniel Iberê Guarani M'byán*: \\ Ana Paula Marques Beato-Canato ${ }^{* * * *}$ \\ Rogério Back
}

\section{Contextualizando}

Em tempos tão difíceis, em meio a uma pandemia que ceifa tantas vidas diariamente em nosso país e no mundo, entendemos ser preciso ter esperança e esperançar, em sentido freireano, I ou seja, arregaçar as mangas e fazer algo que traga alguma contribuição para nossa sociedade, que contribua para a circulação de outras narrativas e nos faça confiar e ter forças para encontrar a boniteza da vida e, ao mesmo tempo, buscar alguma transformação social. Com esse espírito, nós, idealizador/a de uma live com o mesmo título desse texto, vislumbramos a possibilidade de um encontro entre diferentes saberes e estudamos cuidadosamente as pessoas que gostaríamos de convidar para esse diálogo. Em meio a algumas alternativas, entendemos que Lynn Mario e Iberê teriam pontos convergentes e poderiam compartilhar saberes, aprender conjuntamente e nos ajudar a pensar em futuros possíveis, em uma sociedade menos preconceituosa e desigual e mais plural e respeitosa. Fizemos os convites e, então,

\footnotetext{
"Pós-doutor (University of Western Ontario, UWO, Canadá). Livre-docente na Universidade de São Paulo. E-mail: lynnmario@gmail.com.

"* Indígena do povo M’byá Guarani. Doutorando pelo Programa de Pós-Graduação em Antropologia Social da Universidade de Brasília - UNB. E-mail: daniel.ibere@gmail.com.

${ }_{* * * *}^{*}$ Pós-doutora em Linguística Aplicada (Universidade Federal do Rio de Janeiro/UFRJ). Docente na Universidade Federal do Paraná. E-mail: anabeatocanato@gmail.com.

***** Mestrando no Programa de Pós-Graduação em Letras (Universidade Federal do Paraná). E-mail: backruz@hotmal.com. ${ }^{1}$ Assim como Ana Lúcia Araújo Freitas (2020), no livro Leituras de Freire: uma trilogia de referências, optamos por empregar a grafia freireano para manter inalterado o nome do autor, diferente do que indicam as normas ortográficas que sugerem o uso de freiriano.
} 
tivemos a honra de sediar essa live, que, de tão profícua, se transformou nessa entrevista. $\mathrm{O}$ evento ocorreu no dia 04/09/2020, fez parte de uma série de lives organizadas por nossa linha de pesquisa no Programa de Pós-Graduação em Letras (UFPR) em um Webinário nomeado "Conversas sobre Linguagens, Culturas e Identidades" e está disponível no Youtube, no Canal do Programa (https://youtu.be/mMi_wSpesic).

Lynn Mario Trindade Menezes de Souza é professor titular do Departamento de Letras Modernas da Universidade de São Paulo. Linguista Aplicado, atua na área de Letramentos Críticos, Multilingualismo, Políticas Linguísticas, Decolonialidade e Teorias Pós-Coloniais, que procura questionar a hegemonia epistêmica dos saberes ocidentais e meramente humanistas. Para além de sua trajetória acadêmica, com inúmeras publicações e intervenções, sabíamos que o professor estabelece diálogos críticos, de maneira rígida e ao mesmo tempo afetuosa, sobre questões do cotidiano, lendo-se ao ler o outro e a realidade que o cerca. Foi assim que Lynn Mario dialogou com nosso outro convidado.

Daniel Iberê Guarani M’byá, pertencente ao povo Guarani M’byá, é doutorando pelo Programa de Pós-Graduação em Antropologia Social da UnB; mestre pelo Programa de pós-graduação em Ciências Sociais da Universidade Federal do Rio Grande do Norte. Tem atuado em diferentes áreas, especialmente em Sociologia Política e Pensamento Social e participado de conselhos em diversos estados brasileiros. No momento, é professor colaborador da (in) disciplina Arandu Saberes Originários, na Fiocruz, em Brasília, e pesquisador do laboratório e Grupo de Estudos em Relações Interétnicas - LAGERI, vinculado ao Departamento de Antropologia da Universidade de Brasília. Conhecendo-o por uma breve intervenção em um curso de extensão que oferecemos, apostamos que Iberê também estaria disposto ao diálogo e a uma escuta atenta.

Em nossa avaliação, o resultado não poderia ter sido melhor. Assim, iniciamos a apresentação de nossa entrevista.

Ana Paula e Rogério: Para iniciar nossa conversa, gostaríamos que vocês comentassem o título do nosso tex to e como vocês compreendem essa ideia de diálogo entre saberes indígenas e indigenistas.

Lynn Mario: Eu posso começar. Eu acho que é muito relevante nos dias de hoje, especialmente quando assistimos e até participamos de uma situação atual em que os povos indígenas e os povos marginalizados, de forma geral neste país, estão cada vez mais marginalizados e desprezados, onde a grande mídia prefere não discutir outros pontos além do ponto de vista do dominante e hegemônico; então essa conversa é uma oportunidade para abordarmos essas questões. Eu diria que é muito importante e eu prefiro nem comentar o termo indigenista, mas eu vou comentar o termo saberes indígenas, porque, para mim, o termo indigenista é um produto colonial. Tratar de saberes indígenas é uma questão relevante, como o Iberê também irá dizer, porque nós vivemos (e eu estou falando da academia, como professor universitário, como pesquisador de culturas colonizadas de forma geral) em plena hegemonia de um determinado modelo cultural, o modelo ocidental, que nem se chama ocidental, que 
adquiriu e sequestrou o termo universal. Todos os saberes dos povos ocidentais sequestraram essa posição de saberes universais da ciência e todos os outros saberes ficaram com o título de saberes, não como universais, mas denominados saberes locais. Daí o interessante é questionar o que significa 'saberes indígenas', porque se o indígena é local, é pré-colonial, de certa forma todos os saberes são indígenas por terem origem em determinado local. Sabemos que todos os homens têm origem em algum lugar, só que, enquanto alguns escondem suas origens, no caso do ocidente, fazem com que seus saberes pareçam universais, outros têm orgulho delas.

Iberê: Eu fico muito feliz com essa observação, justamente porque se pensarmos na quantidade de povos que existem ainda hoje, só no Brasil estamos falando de mais de 300 (o último censo do IBGE e a FUNAI apontam 305). Então, antes da "bota" europeia pisar nesse nosso solo sagrado e se apoderar desses lugares, dos espaços e dos territórios, éramos mais de 1500 línguas diferentes. Assim, a quantidade de povos era tão múltipla quanto as florestas, que aliás se diversificaram por conta dos povos indígenas, povos originários que aqui se fizeram, se constituíram e constituíram os seus saberes. E aqui existe uma questão central, que seria a valorização e a adjetivação do que é o saber. A ciência se coloca como único centro irradiador dos pensamentos e daquilo que é sinônimo de verdade! Mas essa ciência ocidental é nova e para se constituir ela precisou negar as muitas formas de produzir conhecimento, de interpretação do mundo, e ao fazer isso ela se colocou como o único centro de saber. Então quando falam dos muitos saberes indígenas, dos muitos povos, eu tenho percebido uma tentativa até por parte de alguns parentes de se colocar como uma parte da ciência, de colocar que nós, povos indígenas, também fazemos ciência e, como todos os termos são emprestados, nós os colocamos sempre em uma mediação. Particularmente, eu tenho muita preocupação em afirmar que os saberes indígenas são parte de uma ciência. Na verdade, eu acredito que nós não somos um ramo desta grande ciência: nós somos uma árvore própria enraizada na nossa ancestralidade e, de fato, cada povo tem a sua forma. Assim, cada árvore, cada povo constitui uma diversidade que incomoda! Que incomoda os saberes que são veiculados e que são passados principalmente nas universidades. Quando nós entramos nas universidades, e hoje isso é novidade, os nossos saberes quase não entraram ainda! Se estamos nas universidades, os nossos saberes estão às margens daquilo que se convencionou chamar de saber, de ciência, até porque a vida na universidade parece girar em torno do Lattes, do A1, A2, A3 e das publicações. Então, fala-se muito, e pouco tempo se tem para escutar! Nós, povos indígenas, damos muito valor para o ouvir, então um dos termos que a gente tem ouvido muito é o lugar de fala. Já nós pensamos nos nossos lugares de escuta, dos lugares em que nós podemos nos sentar e refletir sobre aquilo que acontece, sobre aquilo que nos acontece e interpretar o mundo e os mundos às nossas maneiras, sem a intenção de diminuir ou excluir qualquer outro, ao contrário do pensamento colonial, que para se manter e para se constituir precisou apagar, impor um assassinato de memórias (para não dizer dos corpos, dos jeitos, dos lugares...) e precisou negar! Então nós fomos chamados de muitos adjetivos e os nossos saberes também, e não 
apenas os povos originários, mas todos aqueles detentores de saberes que não se enquadram e não se dobram à "ciência". Então somos os charlatões, os que não fazem e não têm cultura, que só têm folclore! Somos aqueles que não produzem um conhecimento livre da tomada de posição e buscamos algo para além da objetividade e da neutralidade muitas vezes pregada pela academia, que, na realidade, nem neutra e nem objetiva é, pois podemos afirmar que ela também tem as suas formas de ser e de defender um mundo que quer colocar para nós, sem nós de preferência! Mas eu queria dizer que nós continuamos, temos continuado vivos como não nos queriam; temos continuado fazendo, refazendo e repensando os nossos saberes, se é que se pode dizer assim.

Ana Paula e Rogério: Muito importante essa reflexão sobre os saberes comumente valorizados pela academia, impregnada pelo que estudos anti e decoloniais têm chamado de colonialidade do saber, que desqualifica, apaga e inviabiliza outras formas de construir conhecimento. Gostaríamos que ampliassem essa reflexão, talvez discutindo as consequências do olhar europeu colonizador, que propôs a separabilidade entre ser humano e natureza, entre corpo e emoção, entre saber e sentimento, entre conhecimento e ideologia, entre povos, línguas, saberes etc.

Lynn Mario: Eu acho importante que você, Iberê, estava lembrando que aqui nós estamos querendo ou não, falando de dentro da academia para pessoas de dentro da academia! E se os saberes indígenas não estão dentro da academia é por resultado de um processo longo de exclusão violenta! Nós estamos aqui "bonitinhos", falando de esperança, de paz, harmonia e amor, mas tudo aquilo que nós chamamos de saber dentro da academia foi conquistado com grande violência na exclusão de outros saberes! E aí vamos lembrar da violência que faz parte da nossa história na academia, porque se nós estamos citando "fulano" é porque nós não estamos citando "ciclano". E se pararmos para pensar, os "fulanos" tantos que citamos são "fulanos" em sua maioria branca, do grande norte global, que têm as mãos sujas de sangue na história colonial! Então, apesar de acharmos que nada tem a ver conosco, nós estamos marcados por essa história de violência! Segunda coisa, Iberê, não sei se convém para a gente dizer que o saber do meu povo é uma outra árvore porque aí, a meu ver, a gente pode cair numa coisa que a ciência ocidental sempre fez e continua fazendo que é a separabilidade. Você lembrou bem que aquilo que nós chamamos de ciência moderna é bem recente, tem uns três séculos, comparado com outras culturas que são atemporais enfim ... (não atemporais no sentido de fora da história, por favor). A ciência moderna, eurocêntrica, se constituiu na base da separabilidade, da separação: começou separando o corpo da mente; separando a razão da emoção; separando o homem que tinha razão da mulher que só tinha emoção; começou separando os povos brancos dos outros povos que, como as mulheres e crianças e animais, não tinham capacidade de usar a razão. Assim, podemos dizer que a base do método científico que herdamos e que fazemos nos nossos trabalhos de pesquisa até hoje, em todos os níveis dentro da academia, é pautada na separabilidade que toma as formas da síntese e da análise: vamos quebrar tudo em partes e separar o conhecimento em partes. Ao fazer isso, separar as coisas em partes, nós estamos 
tirando esses saberes do seu contexto. Lembremos que nesse contexto, há outros saberes, uma pluralidade de saberes até. Não é que esses saberes estão em uma relação de dependência, até que alguns estão por causa de uma história de conquista e desigualdade, mas eu diria que esses saberes convivem duma forma ecológica, interconectados e interrelacionados, alguns mais fortes e maiores do que outros. Vejamos um exemplo disso: no caso, o dos saberes indígenas, especialmente os da grande floresta amazônica: sabemos de tantos casos de cientistas ocidentais que roubaram elementos da natureza e alguns elementos dos saberes indígenas dessa região para transformar em medicamentos da indústria farmacêutica europeia/americana. Ou seja, os saberes não-indígenas se aproveitam dos saberes indígenas e vice-versa! Todos os grupos de saberes são interconectados como todas as línguas, todas as culturas: nós não podemos dizer que existe alguma cultura, alguma língua separada das outras! Então eu acho que, politicamente, em determinados momentos da vida precisamos dizer: "eu não sou você", mas lá no fundo (eu acredito) nós não podemos promover esse conceito de essência cultural, de separabilidade que, como a história mostra, acabou nos destruindo, destruindo o planeta, especialmente quando o humanismo europeu separou o homem da natureza.

Iberê: Gostaria de iniciar com uma consideração sobre a linguagem. Quando percorrem espaços próximos e distantes, as palavras alteram o seu sentido: alguns sentidos se apegam às palavras e outros se perdem; então, uma palavra opera sempre, a todo instante, em oposição ao seu sentido original! Quando eu penso na ciência, essa ciência principalmente positivista, essa ciência que tem separado o fazer do ser, é nela que eu olho e não me reconheço! E quando se olha essa ciência que busca a neutralidade e a objetividade, ela tira algo que para nós é muito precioso: o coração! Quando a ciência vem sequestrar os nossos saberes, ela leva para os seus espaços formais de conhecimento dados mortos: ou os mata na sua escrita; ou os mata em seus laboratórios, tirando do seu lugar, do seu território, aquilo que é mais precioso. Por exemplo: quando eu falo "Ñanderekó", o nosso modo de ser, ele se dá no espaço sagrado de nossos ancestrais, então falar e ser é uma coisa só. Nós aprendemos, por exemplo, e agora eu quero relembrar e rememorar as palavras de che Ru (meu pai) Tata Endy, do meu pai, que dizia que nós somos todos parentes; toda a comunidade é parente; e essa relação de parentesco não termina na comunidade: todos os humanos nós sabemos ser parentes! Nós somos parentes dos humanos e dos não-humanos; somos parentes de tudo que vibra e tudo que pulsa; nós somos parentes dos rios e das montanhas; a serpente é parente do sapo e o sapo é parente da serpente; a canoa é parente do rio e o rio é parente de tudo e de todos os seres que nele vivem. Então, essa nossa relação de completude é uma relação e uma espécie de visão que não separa, muito embora em alguns momentos é necessário marcar algumas diferenças. Por isso, quando nós falamos "nós" ( $\tilde{a} a n d e)$, às vezes nós falamos "só nós" (ore), porque "ñande" somos todos nós, mas "ore" são aqueles que compactuam com "Ñanderekó", o modo de ser. No Guarani, talvez seja mais fácil essa marcação; no português nem tanto. Nesse sentido, a grande preocupação em considerar os saberes indígenas como parte dessa ciência é justamente perceber que ser 
incorporado pela ciência pode significar diminuir os saberes, porque a ciência pelo método filtra algumas coisas que, para os nossos saberes, são muito preciosas, como o pensar, o sentir e o refletir e não apenas a citação de autoridade pelo doutor, pelo pós-doutor. Então, há uma angústia em perceber que, ao entrar em um jogo que tem uma regra que já está dada há muito tempo, pouco ou quase nada nós podemos alterar. Nós podemos, dentro da academia, lidar com alguns termos, mas existem esses limites, e para além desses limites, nós temos "Ñanderekó", que é o nosso modo de ser. Portanto, a preocupação em incorporar e em ser incorporado pela ciência é justamente em função daquilo que se perde, daquilo que se filtra ao entrarmos nesse debate, que, em algum momento, nós olhamos e percebemos que não é tão nosso assim! "Ñande".

Ana Paula e Rogério: Lynn Mario, aproveitando essa fala do Iberê sobre a questão do corpo, da emoção, das perdas causadas por uma compreensão de ciência como espaço da neutralidade e da objetividade, gostaríamos que você explicasse um pouco como entende essa necessidade de trazer o corpo de volta para a conversa e para a academia.

Lynn Mario: Muito importante você lembrar, Iberê, dessa questão do corpo e da inseparabilidade, quando você fala do saber e do ser. Isso é uma das questões que eu comentei das separações que a ciência moderna europeia fez e pelo qual pagamos o preço até hoje, porque, separando a mente e a razão do corpo, a ciência moderna sempre privilegiou aquilo que chamou de objetividade. O que é objetividade? É separar o dizer do corpo; separar o pensar e a razão do coração, do sentir. Então, o cientista não pensa nas consequências do seu saber e de como o seu saber pode afetar o outro, porque ele acha que é capaz de pensar objetivamente sem o corpo, sem empatia. Para trazer um exemplo, estamos sofrendo hoje com a mudança climática. O planeta sob ameaça é fruto dessa separabilidade do saber e do corpo. Isso porque foi esse olhar que possibilitou a produção de grandes saberes, até os saberes econômicos (estou aqui falando do capitalismo), olhando para a natureza e o planeta simplesmente como recursos que podem gerar lucro, como se não tivessem nenhuma ligação com o corpo de quem pensa, porque quem pensa não via o próprio corpo, portanto, não pensava na sua própria sobrevida e muito menos na vida dos outros; e nós acabamos nessa tragédia que estamos vivendo hoje! Eu estou falando isso porque, nos grupos de pesquisa dos quais faço parte, uma das coisas que estamos tentando resgatar é: o que podemos aprender com os saberes dos vários grupos indígenas, reconectando-os à ciência? Os saberes desses grupos indígenas que não fizeram essa separação ainda percebem que o seu saber está ligado não só ao corpo humano, mas a todos os outros corpos não humanos que estão em contato com o corpo humano. Eu chamo isso de trazer o corpo de volta para o nosso pensamento. E aqui eu cito o pensador chileno Humberto Maturana, que começou como biólogo e logo depois passou a ser cientista da cognição, que analisa os saberes sem separar as coisas: um dos termos que ele cunhou é linguajar como verbo. Ou seja, a língua no sentido de comunicação estabelecendo conexões se torna verbo. Ele diz que ao falar a gente estabelece uma conexão com o outro, como você citou no início, Iberê, 
tratando da importância da escuta. Então, ao falar estabelecemos uma relação com o outro e essa relação significa que estamos dizendo em certo plano, inaudível, mas sensível, para o outro, que eu estou aberto a você, não estou apenas falando, mas estou pronto para ouvir o que você tem a falar e sei que eu e você estamos nessa relação de constituição mútua: o que eu sei, em parte, vem daquilo que você sabe e vice-versa. E ele diz que, por isso, a linguagem é amorosidade e vem do coração, pois justamente para usar a linguagem a gente tem que estar aberto e conectado com o outro, na escuta.

Ana Paula e Rogério: Iberê, tomando essas ideias de linguagem como amorosidade e escuta, gostaríamos que você expandisse a compreensão que seu povo tem da linguagem.

Iberê: Eu queria iniciar fazendo um comentário com relação ao vocábulo palavra: o termo em Guarani Nhe'ê, que foi traduzido como "palavra", mas é ao mesmo tempo "som": o som dos pássaros; é o sopro primeiro que desdobra e que desdobrou todos os mundos; é o que habita as montanhas; é o que habita os pássaros; é o que habita tudo que vive; é Nhe'ẽ. Então o que habita o nosso corpo, para nós, é Nhe'ẽ e ele não habita apenas nos humanos: habita os não-humanos, habita os visíveis e os não-visíveis. Portanto, a palavra, para nós, é muito importante! Ela é importante porque guarda o sagrado! Ela guarda a nossa relação direta com o Ambá de onde viemos, que é o sopro também; é o cachimbo é o petenguá, é a fumaça... Então essa palavra é importante porque cria e desdobra mundos, nós aguardamos muito no silêncio, que também é uma extensão da palavra! A palavra dita, então, é aquilo que deveria se aproximar das nossas ações; é M'baraká, a palavra que age; são as nossas ações ou as nossas palavras tornadas movimento! Por isso que nós gostamos de pensar bastante e entramos no mundo de palavras outras e é muito difícil, inclusive. Porque quando nós falamos em português por exemplo, nós aprendemos que uma palavra pode significar ao mesmo tempo uma e outra coisa; pode significar alegria; pode significar felicidade; mas pode significar, também, genocídio, assassinato. Uma palavra pode significar tempos de colheita, de plantio; de plantas livres do sangue; livres do agronegócio; livres do latifúndio; mas a mesma palavra, por exemplo, desenvolvimento ou o agro, pode significar a lona preta; pode significar a expropriação; pode significar os territórios incendiados; pode significar devastação! Então, nós aprendemos e entramos nesse mundo de palavras outras, que significam coisas diferentes, e por isso a gente fala que é a fala do Juruá, palavra que foi traduzida em alguns lugares como o homem branco, mas, na verdade, é aquele que fala da boca para fora, que não compreende a substância ou que não dá valor para a palavra que proferiu. Então, hoje, até mesmo muitos parentes, utilizam Juruá como homem branco ou não-indígena, mas, de fato, não é a aparência que define o indivíduo nem a cor da pele, mas como ele se aproxima das palavras que o fazem caminhar! Eu só queria marcar um pouco esse nosso profundo respeito pelas palavras: palavras ditas; palavras pensadas; palavras ditas e pensadas em silêncio e as palavras silenciadas, impedidas de serem ditas, aquelas que permanecem dormindo, sonhando outros mundos possíveis, de preferência. 
Continuando, eu gostaria de dar um outro exemplo com a palavra suicídio e seu significado para os Guarani. Dentre esses parentes, especialmente dentre os Kaiwoá do Mato Grosso e Mato Grosso do Sul, a média de vida é de 20 anos e eles têm a média de suicídio 12 vezes maior do que a média nacional, e, em Guarani é Jejuvy. E sabe o que que significa? É a palavra sufocada, palavra cortada, palavra impedida de ser dita! Isso para nós é o suicídio, é a morte!

Ana Paula e Rogério: Em muitos estudos da nossa área, definimos linguagem como prática social, conceito que se aproxima da compreensão trazida por você, Iberê. Ao dizer que a linguagem é prática social, estamos entendendo que agimos e nos constituímos na e pela linguagem. Contudo, durante muito tempo (e ainda hoje temos estudos com esse olhar), a Linguística não tinha esse entendimento, não é mesmo Lynn Mario?

Lynn Mario: Muito bem lembrado. A linguística moderna, que preza a tal da separabilidade da ciência moderna, começou a separar a fala do falante, a palavra do significado, a palavra do contexto. Agora é que estamos lutando dentro de uma linguística mais socialmente consciente, para recuperar essas coisas! Em uma das culturas que são minhas de origem, a cultura indiana, a palavra é sagrada! Nós temos os mantras, que nada mais são do que vibrações, porque nessa cultura dizem que, ao enunciar uma palavra, nós estamos expelindo um sopro que vem lá do coração, que nós herdamos dos seres que nos antecederam. Ao virmos a existir, na nossa criação, nos foi dado esse sopro pelos antepassados e, ao enunciar cada palavra estamos emitindo, para quem quiser ouvir, as vibrações que são de toda a vida do cosmos. Então, entendendo a palavra ou não, ela tem efeito; a palavra encanta (você pode ter consciência disso ou não, mas essa força da palavra não deixa de existir). Essa riqueza da importância da palavra, é perdida com a separação da palavra do corpo, do contexto, da história e da natureza. Dentro da Linguística Aplicada, recentemente, estamos recuperando essas coisas, falando de translinguagem, falando da importância do contexto social da língua e de seus usuários etc. Ou seja, não dá para separar a palavra do seu meio, não dá para separar a palavra de quem a enuncia.

Iberê: Eu estava recordando como as culturas originárias de todas as partes do mundo se aproximam muito, mas muito mesmo, nesses valores e a gente encontra pensamentos muito próximos de nós em outras culturas, às vezes, muito distantes geograficamente de nós, nesse pensamento moderno agora, da ciência ocidental, do colonizador que nos distanciou, nos fraturou e nos atravessou de tal maneira, talvez, claro, porque impediu nossa comunicação, mas, em muitas questões, em muitas histórias, nós estamos mais próximos dos orientais, dos indianos, do que do colonizador que está conosco aqui há quinhentos anos!

Ana Paula e Rogério: As interaçôes entre vocês nos fazem refletir sobre o que nos constitui, nos aproxima, nos distancia, nos classifica. Gostaríamos, então, de tratar de algo que tem nos intrigado constantemente, que é a percep̧ão de que vivemos em uma sociedade que muitas vezes menospreza as diferenças ou as reduz a estereótipos. Poderiam, por favor, comentar sobre a construção de uma história 
única contada incessantemente a partir de um ponto de vista e como entendem que suas pesquisas, seus campos de trabalho e suas formas de vida têm visado contribuir para abalar e mudar o rumo dessa história?

Lynn Mario: Eu posso começar dizendo em relação à academia. Nós que pensamos como ocidentalizados etc., achamos que podemos resgatar os saberes dos indígenas basicamente pelo reconhecimento da importância dos saberes indígenas e a sua capacidade de olhar o todo, de não separar o humano do não humano, o vivo do morto, o material do espiritual etc. Mas o que nós temos visto nos últimos tempos, simplificando, são duas posições: uma em que a gente cria um estereótipo de saberes indígenas (de qualquer lugar do mundo) de uma forma simplificada; exemplo disso está nos movimentos como New age em que as pessoas saem por aí abraçando árvores, acendendo incenso e a até recitando mantras da Índia... E acham que ao fazer isso estão recuperando um saber ancestral que pode a todos no planeta. No fundo, essas pessoas não mudaram absolutamente nada! Vestem uma outra roupagem, mas sua maneira de pensar continua a mesma, até porque o que fizeram foi abrir parênteses dentro desse sofrimento planetário atual, e criaram, digamos, uma ficção, um sonho e passam a viver nesse sonho! Uma outra forma de reagir contra a exclusão dos saberes indígenas é através da supervalorização do pensamento teórico e das teorias críticas. E aí achamos que olhando para os saberes tradicionais de alguns povos indígenas de uma perspectiva teórica, que a gente até chama de crítica, estamos usando, de forma positiva, teorias críticas para olhar para e valorizar esses saberes; mas ao fazer isso, o que que eu estou fazendo? Eu continuo dentro do jogo da ciência moderna ocidental! A teoria é onde eu estou usando apenas a razão, apenas a cabeça e não o corpo. Então, eu posso criar as teorias mais mirabolantes sobre a importância das culturas e saberes indígenas, mas o meu ser, a minha amorosidade, a minha maneira de fazer e coexistir com o meu vizinho não mudou! Então, estou "valorizando" alguma coisa da mesma forma que faria ao recitar um mantra, acender um incenso, abraçar uma árvore...; na verdade, não mudou coisa alguma; não valorizei coisa alguma. Afinal o que falta na valorização teórica das culturas indígenas e os saberes indígenas? Falta trazer esses saberes para o corpo, para a ação, para o (con)viver...

Iberê: Eu estou aprendendo muito aqui! Os saberes indígenas, os saberes originários, são saberes enraizados na ancestralidade e quando eu falo saber enraizado é lembrando mesmo de uma planta. Uma planta longe do seu território, longe do seu torrão, ela definha, ela morre. Assim, se nós quisermos valorizar os saberes indígenas, nós temos que, no primeiro momento, garantir o seu torrão, garantir o seu território, porque o saber indígena apartado do lugar em que se pode ser não é um saber! É um livro morto, é uma história contada de algo que pode ter acontecido ou não! Os saberes indígenas são vivos, eles são pulsantes e eles não podem se dar longe dos seus territórios. Se nós levarmos isso na ponta da língua, percebemos que 60\% do Brasil é latifúndio; então, se de fato nós queremos valorizar os saberes indígenas, não podemos botar pastos em cima dos territórios indígenas; ao contrário, precisamos reconhecer os territórios indígenas! O último Censo de 2010 dizia que existiam 1239 territórios indígenas! 
A constituição disse que era necessário dar cinco anos para a demarcação de todos os territórios indígenas e hoje, dos 1239, só 401 são demarcados e quase metade da população indígena está nas periferias das cidades, está nos acampamentos improvisados do lado de fora da cerca! Então, se quisermos valorizar os saberes indígenas, é preciso tirar a pata do boi de cima dos nossos territórios! É necessário tirar a soja de cima dos nossos territórios! Os garimpeiros devem sair dos espaços sagrados em que nós podemos ser e viver! É preciso deixar de construir grandes projetos em cima dos novos territórios! Atualmente, um território indígena é uma ilha cercada de latifúndios por todos os lados! Então, discutir se de fato nós queremos manter vivos os saberes indígenas é entender que eles não se dão fora dos nossos espaços sagrados! Esse é o primeiro ponto. Depois a gente discute se é metafísico, se é pensamento ameríndio ou se os conceitos cabem ou não cabem, qual é a roupa que nos colocam! Mas antes disso é necessário que os próprios indígenas permaneçam vivos ou nós vamos discutir os saberes indígenas a partir das línguas, porque os povos já morreram, assim como aconteceu quando o Museu Nacional foi queimado e seis línguas perderam-se, porque só estavam lá essas línguas. Muitos ficaram tristes e é uma situação alarmante mesmo, mas é também de ficar triste e indignado quando os povos indígenas são massacrados ainda hoje! Os parentes Pataxó estão sofrendo a pressão do Estado; os parentes Yanomâmi estão sofrendo a pressão dos garimpeiros e eu não vou mencionar os 305 porque todos estão sofrendo a pressão de um Estado injusto e decadente, que corta a possibilidade de acesso à água potável nesse momento de pandemia; que corta a possibilidade de, inclusive, identificar quem está contaminado e quem não está contaminado. Há subnotificação! Se você olhar para os dados que o Estado tem divulgado sobre os contaminados, você vai ver que nós não temos dados nem sequer para saber quais povos estão em risco, porque para o governo não importa, para eles somos apenas os "índios", aquele mesmo do equívoco de 520 anos atrás! Então, vamos considerar que o ocidental é tão civilizado que não quis nos diminuir ou nos identificar, que ele apenas se equivocou, porque de fato ele estava indo para a Índia. Mas são 520 anos e o civilizado não percebeu que nós não estamos no passado de uma história que ele é o continuador. Não! Nós somos e devemos continuar sendo protagonistas das nossas próprias histórias. O parente Ailton Krenak nos lembra que os portugueses chegaram ao Brasil degradados, fracos, com fome. Nossos ancestrais os consideraram parentes e lhes alimentaram, lhes deixaram fortes, lhes ensinaram, inclusive, a tomar banho e curar suas feridas. E o que aconteceu? Tem um ditado que diz: trouxeram o seu Deus para nos civilizar, nos trouxeram a bíblia; quando disseram "fechem os olhos", nós tínhamos o território, e, quando nós abrimos os olhos, nós tínhamos a bíblia e eles o território! Então, é preciso pensar sobre o que há de colonizador na nossa crítica contra o próprio colonialismo, o que nos perverteu, o que nos diminuiu, o que tem nos negado inclusive nossas dignidades. Se nós de fato queremos falar sobre os saberes indígenas, precisamos refletir e agir. Nós não temos sequer uma universidade indígena no Brasil. E eu não digo universidade como a que conhecemos ou uma que tenha conceito 7. Eu estou falando de um 
espaço de saber que tenha o mesmo grau de reconhecimento que tem as universidades; nós não temos um espaço que se assemelha a esse! Então, os saberes indígenas são saberes subjugados, submetidos, que existem a despeito das políticas do Estado, porque, se nós fossemos depender das políticas do Estado, nós já teríamos sido eliminados. A própria FUNAI hoje está querendo construir um curso de antropologia para negar a possibilidade dos antropólogos, inclusive indígenas, de entrar nos territórios indígenas. Existem muitas assimetrias sobre os saberes indígenas. Esse é o primeiro ponto. O segundo é considerar que o saber é apenas aquele produzido pela escola! O saber ancestral não é necessariamente produzido pela escola, inclusive a escola, essa instituição do colonizador, serviu para apagar os saberes. Hoje, temos uma luta enorme para o reconhecimento de notório saber dos nossos anciãos, das nossas crianças, dos pajés, das parteiras. Um exemplo muito interessante é o que Minas Gerais tem feito: reconhecer aos detentores de saber o mesmo grau que se reconhece a um Doutor honoris causa. Se nós quisermos discutir de fato os saberes indígenas, teremos que repensar as instituições, as possibilidades de entrada, as escolas e as salas de aula com as suas cadeiras enfileiradas, a entrada e a porta, porque os saberes indígenas não são pautados numa nota no final do mês; não são pautados na presença em sala de aula; não são pautados na disciplina e aceitação daquilo que vem sendo dito por aquele pretenso detentor do saber, que chama todos os outros de "alunos", os sem luz! Nós aprendemos com todas e com todos; aprendemos com as crianças e elas têm direito de voz e de fala; aprendemos com as mulheres, com os anciãos, com todas e todos, porque todas e todos compartilham o saber. E aí muda a lógica: se eu falo compartilhar o saber não é a mesma coisa de vender o saber. O saber compartilhado é aquele que quem quer aprender tem o direito de aprender, porque tem o tempo para se sentar, ouvir, pensar e refletir sobre aquilo que lhe interessa e não essa lógica dada pelas instituições escolares, que, lá no início da vida escolar, na alfabetização, já incute uma forma de pensar ou de não pensar. O não pensamento não tem nada a ver com a ausência de pensamento, mas com o pensamento que impede a produção de outros pensamentos; que incute na criança, desde o início, o comodismo, que premia a apatia, que impede o pensar! Quando criança, você entra na escola e a professora, o professor, diz "desenha essa árvore", e você vai desenhar a sua árvore com as cores que você quiser e a árvore já está pré-desenhada para você; e você vai aprender a escrever e a letra já está pré-escrita para você; e você vai aprender a história e a história já está pré-contada para você, inclusive a história já definiu o que é história e o que é pré-história, a história daqueles que não possuem escrita, e nós ficamos lá no passado! E uma criança indígena dentro de uma instituição desse jeito aprende a ter vergonha de ser indígena porque ela quer disputar, também, o presente que lhe roubaram, um presente que lhe tomaram. Esses saberes, então, são saberes que em algum momento vão ter que dialogar! Nós, hoje, os parentes indígenas, estamos entrando nas universidades. Talvez daqui 20, 30 anos, os saberes indígenas também entrem nas universidades, não sejam apenas os indígenas que estejam entrando, 
DiÁLOGOS ENTRE SABERES INDÍGENAS E INDIGENISTAS: CONVERSA COM LYNN MARIO TRINDADE MENEZES DE SOUZA E DANIEL IBERÊ GUARANI M’BYÁ

mas os pajés que estejam entrando, e formando o ocidental, conversando, dialogando, olhando olho no olho: nem mais alto, nem mais baixo.

Ana Paula e Rogério: Sobre isso, Iberê, em nossa área, a partir especialmente dos estudos de Paulo Freire, temos defendido a necessidade de escuta atenta e de um espaço escolar em que haja diálogo, em que educador/a e educanda/os construam saberes. Mais recentemente, a partir de estudos decoloniais, temos denunciado a violência epistemológica dominante, que classifica e exclui certos saberes, e temos defendido a necessidade de diálogo horizontal entre conhecimentos, o qual Boaventura de Souza Santose Meneses (2009) denominam ecologias de saberes. Apesar dessas propostas, sabemos ser comum a academia se apropriar desses discursos, sem, de fato, fazer o movimento de aproximação. Você poderia falar sobre isso, Lynn Mario?

Lynn Mario: $E u$ acho que tem um aspecto complicado que precisamos levar em conta: dentro do modelo de educação vigente, vemos a falha total, o fracasso do modelo de escola e de educação, que separa o aprendiz do saber, separa as matérias, separa as salas de aula, separa aprendizes por faixas etárias. E claro que valorizamos alguns experimentos, para não dizer experiências, com outras formas de educar: as crianças com idades diferentes ocupando o mesmo espaço, em que o aprendiz define o saber a ser aprendido. Mas enfim, o que queria dizer é que teria um pouco de receio de exigir uma universidade indígena nos moldes da universidade que temos hoje! Eu diria que precisamos questionar o modelo de escola e universidade que temos hoje, totalmente pautado na palavra escrita e na separabilidade ocidental, e exigir o respeito à diferença dos saberes indígenas como tendo o mesmo valor que os saberes que temos dentro de nossas instituições educacionais; precisamos fazer uma distinção entre educação, que é ter acesso à vivência com o saber, e escolarização, que faz tudo menos dar acesso a e permitir a vivência com o saber. Se não fizermos esse questionamento, corremos o risco de simplesmente passar o saber para a escrita e continuar relegando a objeto, um saber, como o saber indígena, com toda a sua riqueza multidimensional, fazendo o simples movimento de transposição desses saberes para um plano bidimensional da página de um livro. Fazendo isso acabamos tirando o produtor daquele saber, a vida, a história de quem produz aquele saber e reduzimos aquela riqueza multidimensional para um saber que se tornou objeto. Cortamos a relação, separamos o saber do seu produtor e o saber vira objeto. O livro é um objeto! Nesse sentido, eu queria recuperar a ideia de que o que, curiosamente, contribui para a não valorização dos saberes indígenas é o fato de não serem escritos; dentro de uma cultura escrita, onde tudo que é escrito é valorizado e tudo que não é escrito não é valorizado, os saberes indígenas são invisíveis! Precisamos trazer esses saberes à visibilidade, mas, talvez, dizer que nem tudo precisa passar para a escrita! O que se faz num contexto tradicional (eu não vou especificar de qual cultura indígena)? Quando nós temos uma mulher contando histórias para os filhos ou um sábio ancião contando narrativas daquela comunidade, não só aos mais jovens, mas aos outros, nós temos o respeito à presença da pessoa que está contando. Isso traz o respeito à maneira em que as suas palavras são apreciadas, entendidas e aprendidas. Por exemplo, nas 
culturas orais africanas, uma mesma narrativa da sabedoria ancestral é entendida de uma forma específica pelos adultos, de outra forma pelos adolescentes, de outra forma ainda pelas crianças. São as mesmas palavras ditas pela mesma pessoa! Quem está contando usa entonação, usa repetição, usa ritmo, enfim... ele pode estar fumando e usando gestos e a fumaça e os gestos fazem parte do ritual, do contato com quem está ouvindo ou assistindo; tudo isso faz parte do saber e de sua comunicação e aprendizagem. Quando passamos esse ritual para o livro sobram apenas as palavras! E, na escola que temos hoje, na universidade, são palavras no livro! Não temos mais o ritual, a magia da presença. Enfim, já não temos mais a valorização da ancestralidade que define quem transmite o saber e qual saber será transmitido; a prova disso é o total desrespeito que muitos de nossos estudantes têm diante do professor hoje em dia, na sala de aula. Por que você precisa do professor? Se há livros, eu posso ler isso no livro! Ironicamente, estamos recuperando um pouco desse valor da presença e do ritual hoje na pandemia, com o ensino remoto, em que os pais estão percebendo a importância do professor e que não basta ler um livro para aprender. Total desvalorização de quem está transmitindo o saber (eu não estou usando transmitir no sentido que Paulo Freire chamou de sentido bancário, mas transmitir no sentido de estar presente ao passar o saber). Então, isto é, o estado atual de nossa escolarização que igualamos a educação! Atualmente estou em uma pesquisa com a África do Sul onde eles conseguiram trazer um pouco dos seus saberes tradicionais para a escola e para as universidades, mas viraram outra coisa e acabaram criando outro problema! Até conseguiram trazer as línguas ancestrais, que foram passadas para escrita e fazem parte do movimento que eles chamam de "intelectualização das línguas ancestrais"; ou seja, tentam transformar essas línguas que antes eram apenas orais em instrumentos de transmissão do saber dentro da universidade. Mas o que aconteceu? Quando passaram essas línguas ancestrais para a escrita, viraram mais um meio padronizado, uma língua separada do corpo de quem a usava. Apesar de ter uma origem ancestral, querem que aquela língua esteja na escrita na escola, que esteja nos livros; ocorre que essa língua, agora escrita nos livros é diferente da língua falada pelos anciãos naquela comunidade e usada em seus rituais. Aquela língua se transformou e se congelou na escola, perdeu a vida, o encanto, enfim.

Ana Paula e Rogério: Aproveitando que Lynn Mario retomou a questão da linguagem (di)ssociada do corpo, gostaríamos de pedir que você nos falasse um pouco sobre o papel da escrita em comunidades indígenas, Iberê.

Iberê: Eu estava me recordando de alguns momentos em que se converte a palavra falada no texto escrito. Estava pensando, como a gente conversou antes sobre como o texto escrito, apaga um pouco das nossas memórias. Os povos originários têm na memória, no dizer, uma marca fundamental e muitos povos indígenas tinham a escrita. Até estava lembrando que Fernando Báez, no livro "A história da destruição cultural da América Latina", nos lembra que, na época da chegada do colonizador, foram queimadas bibliotecas maiores do que as bibliotecas de Alexandria, e isso é muita coisa! Mas, hoje, eu tenho pensado duas formas, porque assim 
como a imagem, isso que a gente está vendo agora, pode servir para manter viva, aos nossos que virão, uma memória e uma outra possibilidade de contar a história. Ela esconde algo que é brutal, como o professor falou, que é a impossibilidade de continuar dizendo e continuar contando as histórias. Por um tempo, diante das ameaças diárias que nossos povos estão sofrendo, pensamos que era preciso botar na escrita histórias e saberes antigos para que não se perdessem, para que não se acabassem. Mas quais são as implicações da palavra escrita e da codificação das línguas? Quando se codifica as línguas, nós, os indígenas, deixamos de ter o direito de dizer. Eu vou dar dois exemplos para vocês sobre problemas de tradução por desconhecimento das culturas indígenas: primeiro exemplo é sobre a tradução feita por Cadogan da palavra Guarani M’byá Jaguar Ovy, para Jaguar Azul (jaguar é onça) e essa ficou sendo a única possibilidade de tradução até hoje. Então, quando nós lemos as traduções sobre os jaguares azuis, que são aqueles jaguares que não morrem - porque a ideia de azul é algo que está em outro lugar, em outro plano, - esse Jaguar Ovy é o Jaguar que não morre, que é um dos nossos ancestrais. Nós então vamos aprender sobre "nós" pelas palavras ditas pelo "outro", que traduziu e que traiu, como deve ser uma boa tradução, mas ele não traiu a língua a que ele falava, ele traiu a língua do povo traduzido, e isso é terrível. Vou trazer outra experiência de tradução do parente Davi Kopenawa, que fala xabiri aos pajés e para os invisíveis. Na tradução do antropólogo Bruce Albert, traduzida depois para o português, está escrito xapiri ao invés de xabiri. O termo xapiri tem sido utilizado equivocadamente e cheguei a presenciar, em sua defesa de doutorado, o parente Apurinã ser corrigido por um membro da banca: "não é xabiri é xapiri, como está escrito". A palavra falada perdeu o tom, em vida, para a palavra escrita de alguém que se quer Yanomâmi era! Então, um grande risco de aprendermos sobre nós pelo outro é esse: limitar a possibilidade do pensamento, separar a palavra daquele que o disse. Nós temos e muitos povos têm os faladores, que são aqueles contadores de histórias: eram Nhe'é Jara, os senhores da palavra; Nhe'ẽ Jary, que são as avós conhecedoras das palavras; os parentes Machiguengas também tem os faladores. Inclusive, Mario Vargas Llosa escreveu um livro chamado "O falador", que narra a importância que tem aquele que disse. Em nossas culturas, tínhamos os Karaí, que eram um pajé dos pajeres, que caminhavam de comunidade em comunidade contando as histórias antigas, contando as histórias do que estava acontecendo nas comunidades e, principalmente, fazendo a sublevação, o enfrentamento, chamando para enfrentar o colonizador. Não era, pelo menos entre os Guarani um enfrentamento principalmente a partir da violência, mas sim uma tentativa de amansar o colonizador, rezando para que ele se acalmasse. Eram danças que duravam horas, dias, semanas, até a morte, para mostrar para o colonizador que a possibilidade de se converter em escravo não fazia parte das nossas culturas, do nosso Ñanderekó. Então era melhor o suicídio que continuar ou permanecer ou se tornar ou ser tornado escravo! E essas danças ecoaram por várias partes do continente, inclusive os Quechua têm danças parecidas; tem no Peru, tem na Bolívia... Então 
era isso que eu estava lembrando quando o professor estava falando que a escrita tem os seus contras e os seus prós.

Lynn Mario: Iberê, a escrita também tem muito a ver com a memória que nós acabamos perdendo no modelo de saber ocidental, porque a gente pensa e quase que naturalizou o conceito da escrita como sendo alfabético. Precisamos recuperar o fato de que em muitas culturas indígenas a escrita ancestral nunca foi alfabética. A escrita ancestral sempre estava presente na forma de desenhos: os hieróglifos dos egípcios; a escrita dos Astecas e dos Maias; as tatuagens e as marcações nos objetos de cerâmica de cada povo... essas são formas de escrita invisíveis diante de uma cultura ocidental que só valoriza a escrita alfabética. E essas formas têm muito a ver com a memória, o que é muito interessante de se ver: como é que se lê um texto escrito em desenhos e não em letras? Porque em letras basta você pronunciar cada letra que supostamente você vai reproduzir o som e a palavra falada originalmente que passou a ser fixada na página. Mas quando se trata de desenho, hieróglifo ou até os petróglifos, que são os desenhos nas cavernas ancestrais, como é que se lê? Depende da memória de quem está lendo! Então, usando a memória de quem está lendo, o texto visual remete ao saber que o leitor já possui; ao ler esse texto visual, o leitor atualiza ou modifica o que ele já sabe; toda vez que um texto visual é lido, é atualizado no sentido de rememorado, recriado, trazido à vida. Por outro lado, um texto alfabético é um texto morto, que não permite variação nenhuma (permite uma variação no seu entendimento, mas aí é uma outra questão). Mas, as escritas ancestrais pré-alfabéticas são escritas que foram feitas para ajudar a memória e o termo para isso é mnemônico. Isso nos lembra um aspecto curioso sobre a escrita, até a escrita alfabética de hoje, que é o fato de a escrita ser sempre tautológica. Isso significa que é repetitiva: a gente só sabe ler aquilo que já sabe ler; a gente não sabe ler nada que a gente já não saiba ler; então, nós ficamos presos dentro das armadilhas da escrita alfabética. Enquanto na escrita pré-alfabética (e eu estou usando pré não no sentido de que houve uma evolução, uma progressão), as escritas mais antigas, não são alfabéticas, são escritas que exigiam a memória, valorizavam a memória; e quem lia, o leitor, não podia ser qualquer um, porque não era qualquer um que tinha o saber para ler esses textos. O texto implicava em refrescar a memória; é aí que eu estou usando o termo memória atualizada. Uma coisa curiosa, Iberê, que precisamos lembrar é que os saberes tradicionais, ancestrais, exigem e desenvolvem a memória de uma forma fantástica, que nós da cultura escrita não conseguimos nem imaginar. Quem consegue repetir uma história ou lembrar de uma história de sua comunidade (e aqui eu digo algo que levaria dias para contar)? Isso é algo possível; muitas culturas têm narrativas longas que faziam isso, mas isso exige técnicas de memorização, recitação e retórica que nós perdemos. Mas é importante lembrar que a memória nunca é apenas repetição: a memória é sempre uma criação, e isso é uma coisa que cria um problema para a antropologia dos saberes indígenas. Como confiar em histórias orais como documentos históricos? Ou eles têm história ou eles não têm história! Uma cultura oral, não escrita, cuja história só existe na cabeça dos que lembram, essa lembrança, essa memória 
não é estável, não é congelada, não é estanque, não é estática. A memória é continuamente atualizada. É um pouco assim: vocês já viram aquelas coisas medievais que são correntes com uma bola no fim, que usavam para prender no tornozelo e dificultar o movimento de um preso? Então, a história é um pouco assim: o passado para uma cultura oral pode ser entendido como aquela bola de ferro no fim de uma corrente. Quando uma pessoa anda, aquela bola anda, mas a distância entre a bola e o tornozelo da pessoa continua igual. Então, nessas culturas orais, sempre há um passado, mas nunca é o mesmo passado. Porque essas culturas tradicionais, quando narram seu passado, pode não ser sempre o mesmo passado; para eles a importância do passado é a sua relevância, aquilo que pode nos ensinar algo hoje! É assim que se cria o respeito para o saber ancestral: perceber e apreciar a relevância que esse saber tem para os dias de hoje. Para isso, os guardiões dessa memória não guardavam esse saber de uma forma estanque, mas conseguiam mexer nos seus arquivos, usando a metáfora do computador, de acordo com a busca. Eles tinham o seu Google e, com isso, atualizavam o saber, tornavam relevante aquele saber para o momento presente e ao narrar esse saber, estimulavam o fascínio desse saber em quem estava ouvindo; e quem estava ouvindo sabia e apreciava a relevância desse saber para o momento. Isso ajudava e contribuía para a preservação e a valorização do saber. Isso tudo pode ser perdido se simplesmente transferirmos esse saber para a escrita e para livros.

Ana Paula e Rogério: Iberê, você gostaria de ampliar a discussão sobre a questão da memória para os povos indígenas e sua relação com a linguagem, no sentido que mencionou anteriormente, ou seja, a linguagem como o que nos constitui e carrega sentimentos, vivências etc.?

Iberê: Memória vem do latim měmorōris, o que se lembra. Uma palavra muito próxima é recordes, recordação: re-cordes, é o que volta a passar pelo coração. Então, a memória é aquilo que volta a nos passar pelo coração e essa é a base do que ficou esquecido e do que tem sido negligenciado como um saber menor do pensamento ocidental. Porque o coração tem sido colocado de fora e tem se valorizado muito o intelecto, como se ele tivesse distante do coração; as pessoas apenas pensam e pouco sentem: são ensinadas a pensar e pouco a sentir. Então, se a memória é aquilo que volta a passar pelo coração, o que nós recordamos é aquilo que nos causa algum efeito, aquilo que nos passa, aquilo que nos fere, aquilo que nos toca. Só o que arde permanece vivo na memória; uma casa incendiada permanece viva na memória; uma arbitrariedade permanece viva na memória; um momento de debate permanece vivo na memória. Um livro aberto ou fechado tem mais dificuldade para permanecer vivo na memória, a menos que nós nos sentemos como quem conversa para aprender e isso nos textos escritos da academia há muita dificuldade. É mais fácil ouvir um poema, uma narrativa, um conto, porque ele se aproxima do que volta a passar pelo coração. Então, sobre a escrita, eu estava lembrando daquilo que é para além do texto escrito, e aí eu vou me permitir uma divagação: para nós é escrito os nossos ypara, que muitos povos chamam Kenẽ, são esses desenhos, e há uma relação muito profunda com o sagrado. Existem pinturas para a cura, que você desenha para que aquela pessoa permaneça ou esteja curada ou protegida; existem desenhos para o 
enfrentamento, se diz guerra né; existem desenhos para marcar as direções (estou usando desenho, mas para nós é ypara); existem desenhos para marcar o grupo a que nós pertencemos; para marcar o momento na vida em que nós estamos; para nos dizer a direção do nosso coração. Por isso que muitos povos hoje ainda não usam tatuagens (para a nossa cultura, claro, pois tem alguns povos que são diferentes), porque um desenho feito no teu corpo indica uma maneira de pensar, de ser e de agir. É uma pele que tu vestes! Por exemplo: um desenho de um gavião para ver com mais profundidade e com mais amplitude; se eu quero ir ao mundo das águas, o desenho do gavião não me serve. Então, um desenho é temporário e é provisório para que nós aprendamos a nos desapegar nesses nossos caminhos. Aprender a nos desapegar tem um pouco da resposta daquilo que uma pergunta que apareceu aqui: o que fazer? Nós apenas vestiremos esta roupa dada pelo colonizador? A roupa dada pelo colonizador é "uma" roupa, que pode ser muito confortável e, por estar durante muito tempo, parece que é parte do próprio corpo, mas é "uma" roupa. Nós podemos aprender a nos desvestir, a nos despir, a trocar, a dizer "essa roupa não cabe em mim, essa roupa é um espinho que está me machucando"! É claro que não há certeza de qual outra roupa eu terei que assumir e por isso muitos acabam se acostumando e dizendo: "é, o mundo é injusto, mas assim é o mundo". Então, nós aprendemos que o desenho escrito nos diz o que nós lemos. Mas a leitura não está apenas aí (e aí eu estou me permitindo sair para um outro caminho que talvez não faça nenhum sentido para vocês): a ler o rio e o tempo do rio, porque isso pode significar cheia, pode significar piracema, pode significar água poluída nesses tempos todos, a ler o canto do pássaro, porque como ele canta e como ele voa significa como o mundo e o nosso território está se comportando... Ou a falta do canto do pássaro, ou a falta do escuto da onça diz também sobre o que avança sobre os nossos territórios. São outras leituras possíveis para ler o texto escrito. Então, o poder desse saber, o saber colonial, criou o centro e se colocou nele e criou as margens, as periferias. Ao criar o centro e as margens, ele elegeu o que era principal e colocou aquilo que ele descartou às margens. Os saberes dos povos originários não possuem margens, eles se desdobram como ramagens e cada ramagem é possibilidade para o abrir, para o desabrochar de uma outra flor de conhecimento. São possibilidades de leituras, né?

Lynn Mario: Iberê, eu fiz um estudo muitos anos atrás com os Huni Kuin e seus desenhos de suas mirações com a ayahuasca ou o cipó, e isso me levou a olhar outros desenhos na cultura escrita. Isso nos fins da década 80 eu chamava de multimodalidade, que na época não era um termo tão conhecido. Hoje em dia, é um termo bastante usado e muita gente acha que a tal da multimodalidade - usar vários modos de significar, através da imagem, através da palavra alfabética - é algo que vem da cultura digital no computador. Na verdade, a multimodalidade é muito mais antiga. Eu queria contar essa história, essa minha experiência na década de 80. Uma das coisas que você bem disse e que eu aprendi com os Huni Kuin é que, nos desenhos que produziam baseados em narrativas que 'viram" em mirações, um desenho remete, digamos, a um personagem de uma narrativa (você citou águia, jaguar, e o que for), e 
não é só animal; enfim, o desenho no texto visual remete a um personagem dentro de uma narrativa; e é a narrativa que vai contar o que significa esse personagem, esse ser. Então, a sabedoria é passada, é lembrada, através de uma narrativa que contém esses seres que depois são reproduzidos como desenhos, tatuagens e objetos do cotidiano. $O$ desenho remete àquele personagem daquela narrativa; então, quem conhece a narrativa já sabe a importância e o significado do desenho naquele objeto, naquela peça de roupa, enfim. Eu estava fazendo essa pesquisa, lá na década de 80, quando eu recebi um convite da Universidade de Atenas, de quem fazia Estudos Clássicos da cerâmica grega e eu pensei: "não tem nada a ver comigo, eu não estudo isso, deve ter vindo errado" (naquela época os convites vinham por carta) e ignorei o convite. Aí veio outra carta dizendo: "não! Nós vimos e soubemos da sua pesquisa e por favor venha e você vai ajudar o nosso estudo aqui”. Lá fui eu! Eles estavam estudando os desenhos nas cerâmicas gregas antigas (os próprios gregos estudando os gregos antigos em Atenas), e eles estavam brigando contra o que eles chamavam de tradição cultural ocidental, porque eles se acham colonizados pelos alemães, ingleses e franceses, que preferem olhar para a cultura grega através do olhar romântico do século 18. E eles estavam dizendo que esses desenhos não são só decorativos; e certa vez ouvi-los dizer: "não são só decorações, remetem a sabedoria ancestral da comunidade". E aí pegaram essa dica de meu trabalho para mudar a linha da pesquisa deles e aí eu falei: "meu Deus, que sensação estranha! Eu que critico o saber ocidental e cá estou eu no suposto berço do saber ocidental, a Grécia, e estão me dizendo que estão aprendendo alguma coisa com as culturas indígenas da Amazônia" - risos - Aí você vê como o mundo dá voltas e as coisas não se separam tão facilmente assim.

Ana Paula e Rogério: Gostaríamos de dar um direcionamento para a questão da formação: como poderíamos pensar em formar professores/professoras que tivessem um olhar mais sensivel para as questões levantadas aqui e possam contribuir para mudar um pouquinho dessas histórias únicas tão enraizadas na nossa sociedade?

Lynn Mario: Eu posso começar porque eu trabalho com a formação de professores, mas não da forma como eu gostaria agora porque a instituição dificulta. Eu queria recuperar algumas coisas que já dissemos: a importância do saber ancestral; a importância do território (o Iberê já falou sobre isso), ou seja, o local de onde nós estamos falando; a importância do corpo, ou seja, eu não sou uma mente desconectado do meu contexto, a minha mente pensante está localizada dentro do meu corpo ocupando um determinado espaço geográfico, com uma história, uma ancestralidade dentro desse espaço. Só que esse espaço é atravessado por outras presenças; não é um espaço que eu individualmente ocupo. Eu não posso dizer que eu estou falando de um espaço ocupado por mim como um indivíduo, porque a minha língua eu aprendi com os outros, ou seja, eu não nasci falando; aquilo que eu sei eu aprendi com os outros, não nasci sabendo; a maneira que eu me comporto e me sinto diante dos outros também aprendi com os outros. Então, esses outros ocupam esse espaço de onde eu estou falando. Aparentemente, eu estou falando sempre do mesmo espaço, mas não é isso, porque 
esse espaço é atravessado toda vez que abro a boca para falar, porque, apesar de poder ter passado um tempo, nesse tempo, eu me expus a outras influências, outras conversas que me afetaram. Isso significa que eu posso dizer sempre que eu estou falando de um determinado local, mas esse local nunca é o mesmo. O importante é a ancestralidade desse local, porque, embora a história nunca seja a mesma, é sempre história; é sempre a minha história; é uma história que está em constante transformação, atualização, na medida que vou vivendo. Uma das coisas que eu aprendi muito quando eu estava fazendo pesquisas com os povos indígenas da Austrália, da Nova Zelândia, (não sei, Iberê, dos Guarani) é uma crença de que a gente só pode andar para o futuro de costas, olhando para o passado. Significa o que? Significa que todo o conhecimento que me leva para o futuro vem da minha ancestralidade! Eu sou aquilo que aprendi a ser com a ancestralidade! Então, eu ando para o futuro não porque eu sei qual é o futuro, (esse é o problema das nossas utopias: nunca temos as nossas utopias porque na verdade não existem, precisam ser construídas), mas porque eu ando com a bagagem da minha ancestralidade e isso é uma coisa muito importante, para mim, para a formação de professores: de eles respeitarem tudo aquilo que aprenderam e aprenderem que aquilo que aprendem e aquilo que estão ensinando e a relação que eles têm com os seus alunos aumenta o seu saber o tempo todo. Então, ser professor é saber aprender. Pertencer a uma cultura tradicional oral é saber aprender e respeitar o valor de aprender constantemente. Nós de uma cultura escrita achamos que ter um livro embaixo do braço ou na mochila significa saber e poder dizer que é foucaultiano ou bakhtiniano, por exemplo, como se nada faltasse no meu saber. Então, essa coisa de andar de costas para o futuro nos traz a humildade de saber, de lembrar, que não sabemos: estamos constantemente aprendendo.

Iberê: Eu gostaria de falar que os saberes dos povos indígenas são saberes em movimento. Então, nós trocamos muito e aprendemos bastante com vários povos. Existem, inclusive, povos que não se casam com as pessoas do mesmo povo, que fazem com que esse compartilhar seja algo da cultura e da maneira, como por exemplo os povos Ye'pâ-Masa, os Tukano, os povos chamados Tukano que se casam com Desana, enfim, com outros povos que estão no lado e, então, aprendem outras línguas, aprendem outras histórias, as memórias vão se fazendo e, principalmente, o compartilhar das coisas. Uma possibilidade é pensar a escola não apenas aos povos indígenas, mas pensar a escola mesmo, como um espaço de partilha. Imagine, a gente fala de uma Base Nacional Comum Curricular, isso parece muito bonito, mas tem algumas coisas que talvez sejam necessárias de pensar: se eu aprendo aqui a mesma coisa que, como diriam os antigos, desde Cortella, o mesmo Ivo vendo a uva, eu só vou ver a uva, não vou ver o açaí, não vou descobrir nem que o Buriti dá para fazer vinho melhor do que a uva, não vou aprender sobre os patoás, sobre a bacaba, sobre o Buriti. Ou seja, se todo mundo aprender a mesma coisa, vai aprender a valorizar "uma" forma de ser e "uma" forma de saber. Mas isso não é apenas para os povos indígenas; é também, para os povos tradicionais, é também o que é mais evidente. Temos aí uma escola apartada do seu território, que não sabe dos fazedores, 
dos detentores dos saberes que estão em volta das escolas. Um convite, então, é para as professoras e os professores pegarem os estudantes e dar uma volta, não apenas chamar alguém para ir à escola, como esse local formal do conhecimento, mas levar para conhecer aqueles que estão próximos das escolas, mostrar o que há, o que pulsa vivo de cultura ali perto mesmo. Provavelmente alguns vão encontrar sabe quem? Os seus pais, as suas mães, os seus avós, aqueles que detém um saber que não entra na escola e vão aprender que os seus pais, as suas mães, os seus avós, os seus tios, enfim, são também pessoas que devem ser levadas em consideração tanto quanto Piaget, Derrida, Foucault, todos esses, porque eles, mais que ninguém, conhecem aquela realidade e podem pensar também coletivamente àquela mesma realidade. Então, nós podemos aprender sobre preconceito de muitas formas; nós podemos aprender sobre desigualdade de muitas formas. Nós podemos aprender sobre desigualdade aprendendo sobre as relações do Capital, lendo o Capital, aprendendo sobre Marx, Gramsci, Engels e todos os autores. Nós podemos aprender a questionar o Estado lendo o Bakunin, Daniel Guérin e todos os anarquistas. Nós podemos aprender sobre dominação com um prego na parede como Boal falou, em que ele foi dar uma aula e pediu que batessem uma fotografia do que é essa opressão e um guri chegou com uma foto de um prego na parede. Aí muitos pensaram "Ah, ele não soube, não entendeu o que significa aquilo". Aquele prego na parede, no Peru, era um prego que um engraxate alugava para colocar a sua caixinha, porque era muito pesada, para não ter que voltar para casa. Para ele aquilo era opressão, ele não precisou ler O Capital para entender (embora seja importante), mas ele fez uma leitura que está para além do texto escrito. Então, se nós pensarmos, também, que podemos aprender não apenas dentro das escolas, nesse ambiente de escolarização, mas com os fazedores que estão em volta e pensar a comunidade como parte desse fazer e desse ensinar, aí talvez possamos tornar a educação algo muito mais afetivo e menos impositivo, com características e relações similares a organizações como a prisão ou o hospício, como vocês, que são da linguagem sabem mais do que eu. Então, talvez, a escola possa ser uma coisa diferente. Não podemos esperar que o estado faça isso, que o presidente faça isso, talvez nós, cada uma e cada um de nós podemos falar sobre essas experiências e seus limites. Para citar um exemplo, fui convidado para dar uma aula em um curso de formação para os professores indígenas no estado da Bahia no final do ano passado. Vejam, 520 anos depois da chegada dos colonizadores na Bahia, em Porto Seguro, é a primeira vez que estava tendo um curso de formação para indígenas, sobre saberes indígenas, dado por indígenas. Ao chegar, os professores estavam sentados em cadeiras enfileiradas, aguardando o PowerPoint, com citações de autoridade. Ao contrário dessas expectativas, nós fomos aprender não comigo ou com qualquer outro professor; nós fomos aprender com os pajés; eles estavam longe e nós fomos fazer uma visita para aprender. Nós fomos fazer uma visita para aprender sobre os cantos e rituais dos parentes Pataxó; nós fomos fazer uma visita para aprender sobre as plantas originárias que ainda se cultivam e, na cidade, nós fizemos algo que a gente chamou de caçada: sair para caçar. A gente fez os nossos cantos de caça e passou a noite se preparando 
para caçar. No outro dia, a gente permaneceu em silêncio para a caçada. E o que que a gente foi caçar? A gente foi caçar as marcas do colonizador nos espaços dos territórios do povo Pataxó; nós fomos tentar entender como pensa, como age (aquela história do que come, como eles fazem conosco); nós fomos no museu dos povos indígenas e tinha muita coisa lá importante, só não tinha nada que falasse sobre os parentes Pataxó no território Pataxó. Tinha um guia que contava a história de como os Pataxós eram no passado, que não existia Pataxó ali. Esse guia contou essa história para os Pataxó que foram ouvir. Essas são marcas da colonização! Nós fomos ver o local mais antigo de lá e uma professora depois permaneceu em silêncio. Quando a gente voltou e foi fazer o que a gente faz depois de uma caçada, que é partilhar a caça, essa professora compartilhou com a gente que ela tinha nascido e crescido vendendo ali na frente daquele lugar e nunca tinha entrado. Ela perguntou se a gente tinha olhado as telhas daquelas casas, que cada uma era diferente da outra e era diferente porque aquelas telhas foram feitas nas pernas das mulheres Pataxó, que nunca puderam entrar no museu, que tiveram suas histórias apagadas! Então, são muitas possibilidades que a gente pode fazer fora da sala de aula, porque, por melhor resolução que tenha a fotografia de uma árvore, de um parente, nunca será igual a ela viva, enraizada. No contrário, nós aprenderemos as nossas histórias, as nossas educações, pelas fotos, pelas fotografias dos livros, sobre as árvores pelas fotos porque quase acabaram com a floresta e com todos os biomas, o cerrado e tudo mais... São possibilidades. Então, o convite é utilizar a escola como lugar de encontro e depois sair para caçar, ver o que que há, o que que permanece apagando e oprimindo os muitos saberes. Mas é um convite, eu estou só aqui pensando.

Ana Paula e Rogério: Achamos que é um convite lindo! A nossa intenção com esse encontro era justamente tentar estabelecer um desses convites também para que possamos nos aproximar. Entendemos que essa aproximação é crucial para conseguir desmistificar visões enraizadas e abalar a história única contada pelo colonizador, que privilegia formas de ser e saber, invisibiliza e inviabiliza outras formas e se beneficia dessa narrativa opressora, preconceituosa e violenta. Para finalizar, gostaríamos de agradecer imensamente por vocês terem abordado todas as questões previamente enviadas de forma aprofundada, crítica, mas leve. Aprendemos muito com vocês e finalizamos com muitas inquietações, olhando para o sistema do qual fazemos parte de uma forma ao menos um pouco diferente e com vontade de esperançar no sentido freireano, de ter coragem de fazer diferente. Ainda estamos no meio de uma pandemia, com um vírus que contamina tão facilmente, que já ceifou milhares de vidas, nos entristece e nos deixa perplexos. Que a gente possa pensar em outras formas de contaminação: que os saberes de vocês nos contaminem para que a gente olhe diferente e consiga construir novas realidades. Essa é a nossa esperança e expectativa. Temos muito a agradecer por todo o compartilhamento de vocês! Gostaríamos, entãa, de convidar vocês agora para trazerem suas palavras finais.

Lynn Mario: Eu só queria dizer duas coisas: primeiro, o que nós tentamos fazer aqui não é para vocês saírem por aí consumindo, comprando, tentando se tornar indígenas. Não é comprando um cocar e usando um cocar que você vai se tornar indígena. Então, não é 
comprar o saber indígena, é se expor a esse saber, aprender como as pessoas pensam e são, de formas diferentes para que a gente se torne diferente. Não para que a gente se torne no outro. A segunda coisa que queria dizer é a necessidade de recuperar a amorosidade com a qual começamos aqui, com o coração, sem o qual nenhum de nós estaríamos aqui. O importante da imagem do coração é que o coração não bate por ele mesmo, o coração bate para o resto do corpo para que o sangue circule pelo coração. Então, o coração é a metáfora, para mim, da importância da ética de ser para o outro, de viver em função do outro e perceber que não há uma separação entre o eu e o outro. Obrigado.

Iberê: Quero agradecer do fundo do coração à Ana Paula, o Rogério, ao professor Lynn Mario que me engrandeceu e eu aprendi muito. E a todas e todos que estão por aí ouvindo/ lendo de alguma forma, que dedicaram seu tempo para nos ouvir/ler. Eu convidei para a caçada, mas nesses tempos, para os vegetarianos, vamos fazer uma pescaria ou para os veganos, vamos fazer uma colheita. E quem colhe precisa plantar, vamos plantar então sementes de liberdade nas primaveras desse mundo porque isso nós sabemos fazer. Talvez o compartilhar seja algo que todas e todos nós temos em comum. Precisamos daqueles que estão esquecidos; precisamos (re)lembrar, fazer com que tudo volte a passar pelo coração e partilhar o afeto. Isso tornará as nossas vidas muito mais bonitas, muito melhores de serem vividas coletivamente. Então gratidão mesmo, Aguyjé veté! Nde'recó porã guaquera! Quero deixar um salve a todos os parentes que puderam nos acompanhar e eu estou aqui com o coração muito perto de todas e todos. Gratidão mesmo. Aguyjé veté!

\section{REFERÊNCIAS}

BÁEZ, F. A história da destruição cultural da América Latina: da conquista à globalização. Rio de Janeiro: Editora Nova Fronteira, 2010.

BOAL, A. Teatro do oprimido e outras poéticas. 7 ed. Rio de Janeiro: Civilização Brasileira. 2005. CADOGAN, L. Aywu Rapyta: textos míticos de los Mbyá-Guaraní del Guairá. São Paulo, 1959. FREIRE, P. Pedagogia da esperança: um reencontro com a pedagogia do oprimido. Rio de Janeiro: Paz e Terra. 1992

FREITAS, A. L. A. Leituras de Freire: uma trilogia de referências. Porto Alegre: Editora BeM, 2020. KOPENAWA, D.; ALBERT, B. A Queda do Céu. Palavras de um xamã yanomami. São Paulo: Companhia das Letras, 2015.

SANTOS, B. S.; MENESES, M. P. Introdução. In: SANTOS, B. S.; MENESES, M. P. (Orgs.) Epistemologias do Sul. Coimbra: Edições Almedina, 2009. 
VARGAS LLOSA, M. O Falador. Tradução de Remy Gorga Filho. 3. ed. Francisco Alves, Rio de Janeiro, 1988.

Recebido para publicação em: 24 jun. 2021. Aceito para publicação em: 29 jul. 2021. 